\title{
GLOVES IN BOXING
}

\author{
J. L. BLONSTEIN ${ }^{1}$ and L. SCHMID ${ }^{2}$, MUDr., CSC., \\ ${ }^{1}$ President, Medical Commission A.I.B.A. \\ ${ }^{2}$ Member of Medical Commission of A.I.B.A.
}

Charles University, Prague

It is over 200 years since the use of gloves was introduced in boxing by Broughton in his Boxing School in England in 1743. Since that time boxing gloves have gone through a number of changes, both as far as the form and padding are concerned.

In boxing circles the effect of the blow with a glove of various weights is often discussed. It is generally accepted that the blow aimed with a glove of a lighter weight is harder and thus more dangerous for the opponent. That is why in 1948 there was an endeavour to prescribe for amateurs gloves of different weights according to the weight of the boxer. From fly to light-weight 8 oz., from welter to middle-weight $10 \mathrm{oz}$. and for light-heavy and heavy weights $12 \mathrm{oz}$.

The rules of today demand use of gloves for:

Professionals - 6-8 oz.

Amateurs - 8-10 oz.

Juniors - 12-14 oz.

The surface of the gloves is of fine, smooth leather.

For the receiver of the blow it is significant if the gloved opponent's hand is half-open or if it is tightly closed. Of great importance either for the hand of the boxer aiming the blow or for the one who receives it - is the position of the thumb. Unfortunately the format of some gloves is poor, the thumb is free and so it gets easily injured by the blow. That is why the form of gloves should always allow for the fist to be closed tightly and the thumb to be close to the fingers. (Laymen sometimes believe that the thumb is tightly closed inside the rest of the fingers). In this way many thumb injuries can be prevented (Wolff, LaCava, Klaus, Moskwa, Illouz). At present we consider gloves manufactured by the German firm of BERG as being the best. They are mostly used, for example, during the Olympic Games, the European Amateur Boxing Championships and at various international matches.

Montanaro and Francone obtained results from a roentgen-cinematographic study. The various movements of the wrist and of the hand properly bandaged and covered with an $8 \mathrm{oz}$. glove were compared to those of the hand closed in an unbandaged fist, in the regular positions as well as in the technically wrong blows. Then, formulating some pathogenetic assumptions, they correlated the occurence of some fractures of the metacarpals and the carpal bones to the incongruous position in which the hand is forced in the glove and to the modalities of technically wrong blows.

Bandaging and gloves will be changed in order to limit the amount of fractures affecting the hand in boxing.

Padding of the gloves was of horse-hair. Many discussions took place about the padding, mainly when Lofgren brought the idea of replacing horse-hair by air as in the tyre. The pressure of air in the glove has, of course, to be controlled by a manometer. The weight of the new Lofgren glove is 13-16 ozs. The author affirms that lesions of the brain do not occur when these gloves are used as may happen with the gloves filled with horse-hair. The idea may be good, but technically these gloves are difficult to use (Lofgren, Tietze, Moskwa and others).

Other padding which has been accepted is felt, plastie materials, e.g. polyurethane, fine foam rubber, a specia kind of sea sponge (Jugoslavia) and special liquid (Italy).

When measuring experimentally the influence of the boxer's glove on the intensity of the blow it appeared that the boxer's glove has a considerable influence on damping the blow. The effect of the blow was registered by the crystal gauge KB-11-MMF placed on a wooden fist with the use of transistor registering apparatus (SDM 132) and a loop-oscillograph (M-700) from the USSR. From the measurements the decrease of blow intensity was in the range of $40 \%$, while the differences between the individual weight of gloves $(8,10$ and $12 \mathrm{ozs})$ are not very significant (Schmid). That is why it is not possible to state uniformly that increase in the weight of boxers' gloves would have a marked effect on diminishing the danger of injury in boxing.

Perhaps it would be advisable to put more stress on the necessity that boxing with old, worn out gloves, with padding pushed to the sides should not be permitted.

No matter what is used for the padding of the glove chosen, the boxer's style i.e. the way of aiming the blow - will always be decisive for prevention of injury of his own hand.

The bandage on the one hand serves as a safeguard to the hand aiming the blow, but it also decreases the

$$
\overrightarrow{.}
$$


intensity of the blows. Gebhardt in 1965 made an intensive comparison of the kinds of bandaging in proportion to hand injuries. With regard to the average number of bouts the bandage forms were compared between the cases with and without injury. It has become clear that the use of the normal bandage offers the least protection to the hand. The cross and finger bandage showed to be far more effective. This fact leads to the proposal to create a fingercross-bandage. This will be possible if the usual bandage is elongated by approximately $50 \mathrm{~cm}$. As far as material is concerned, it corresponds to the generally used "Cambridge Bandage" at the present time.

Lengthening of bandages would undoubtedly have significance in greater protection of the boxer's hand joints, but on the other hand it would mean a harder blow for the opponent.

It is also important to comment on injury prevention. Many boxers do not use bandages while training with apparatus, and it is understood that hand blows without bandage protection on the punch ball or bag, may also damage the bones of the hand. It is also necessary to warn against the bad custom of letting the boxer, before the match, strike the wall with the gloved hand. Hand injuries can also be caused in this way.

To safeguard against injuries of the thumb and bones of the hand in general, it is also necessary to warn against prolonged striking of the punch bag (Cermák).

\section{REFERENCES}

1. BLONSTEIN, J. L. - SCHMID, L.: Boxing and Medicine/Manuscript.

2. CERMAK, J. (1957): Boxing CSSR, 7, 194.

3. GEBHARDT, E. A. (1965): Sportarzt-Sportmedizin, 16, 280.

4. ILLOUZ, G. (1967): Med.Educ.Phys. Sport, 41, 42.

5. KLAUS, E. J. (1940): Munchen.med.Wschr., 87, 265.

6. LaCAVA, G. (1949): Le fratture della mano nel pugilato. Rome. F.M.S.I.

7. LOFGREN, L. (1957): Medicina sportiva, 11, 449.

8. LOFGREN, L. (1961): J. Sports Med. \& Phys. Fitness, 1, 23.

9. MONTANARO, M. and FRANCONE, A. (1966): Proc. 6th Intern. A.I.B.A. Med.Congr.Rome, 7.

10. MOSKWA, J. (1956): Kultura fizyczna, 10, 374.

11. MOSKWA, J. (1959): Boks (Warszawa), 2, 15.

12. SCHMID, L. (1970): Medizin un Sport, 10, 117.

13. SCHMID, L. et al. (1968): Cas. Lek.ces. (Prague), 107, 940.

14. TIETZE, K. (1959): Theorie Praxis Korperkultur, 8, 273.

15. WOLFF, K. (1928): Dtsch.Z.Chir., 208, 379. 